\title{
Feasibility of Slum Redevelopment in Ghana: The Regenerative Approach
}

\author{
Esther Duah $^{1, *}$, J. T. Bugri ${ }^{2}$ \\ ${ }^{1}$ Ghana Institution of Surveyors, Kwame Nkrumah University of Science and Technology, Ghana \\ ${ }^{2}$ Kwame Nkrumah University of Science and Technology, Ghana
}

Copyright $(2016$ by authors, all rights reserved. Authors agree that this article remains permanently open access under the terms of the Creative Commons Attribution License 4.0 International License

\begin{abstract}
Slums are tagged as home for the urban poor and have been described as one of the world's most life threatening environments because of their extremely poor environmental and housing conditions. Their existence has often caught the attention of political leaders because of their obvious drag on the national development agenda of developing countries. The nature of the slum problem has often led to calls for "slum-free" environments from politicians and development practitioners alike. Yet, from the perspectives of slum dwellers themselves, slums are places of socio-economic livelihoods in which they do recognize the insufficiency of their environments but possess limited capacities in changing these conditions. They appear crippled by the hopelessness of poverty and inadequacy to cause any such dramatic change in their environments. The United Nations millennium development goal 7 target 11 gives the task of achieving significant improvement in the lives of at least 100 million slum dwellers by 2020. This emphasizes the world's recognition of the need to actively intervene to bring about improvement in the lives of slum dwellers. This paper discusses the approaches that have been used in dealing with the slum problem in the country which has been retrogressive so far as against the prospects of the regenerative redevelopment of slums. Detailed empirical data on the Anloga-Sobolo township in the Kumasi Metropolis is used to examine the feasibility of regenerative slum redevelopment in Ghana as propounded extensively in literature. The township is characterized by haphazard development of an originally planned township due largely to rapid urbanization and weaknesses in land policies and planning system. The subject secondary data was primarily collected between 2009 and 2010 for a case study sample a sample size of 180 individual stakeholders and three (3) institutional stakeholders. It is the conclusion of the paper that while slum redevelopment is feasible in Ghana, the regenerative redevelopment approach is more likely to attain "slum-friendly" environments as opposed to the slum clearance approach based on the notion of "slum-free" environments. It is thus recommended that political will to commit resources to a priority programme of slum
\end{abstract}

redevelopment in the long-term by governments is needed to make headway in slum redevelopment in Ghana and the developing world as a whole.

Keywords Slum, Feasibility, Regenerative Redevelopment, Urbanization, Ghana

\section{Introduction}

The definition of a slum has been the subject of much academic and political discourse with the term assuming both objective and subjective connotations. Its subjective connotation has led to an embedded element of relativity in its definition: thus the statement - "slum is only a slum in the eyes of some" [1]. However, the elements of subjectivity and ambiguities about the definition of 'slum' cannot play down the fact that slums do exist, and most observers would agree on the classification of areas into slums and well planned settlements. A slums has been popularly defined legislatively as 'any area where dwellings predominate which by reason of dilapidation, overcrowding, faulty arrangement or design, lack of ventilation, light or sanitation facilities or any combination of these factors are detrimental to safety, health or moral'[2]. Drawing from the foregoing definition, the UN Habitat [3] has described 'slums' as having the following characteristics:

- $\quad$ Poor structural quality of housing

- Overcrowding

- Inadequate access to safe water

- Inadequate access to sanitation and other infrastructure

- Insecure residential status

- Low incomes and socially deprived inhabitants.

It is this UN Habitat definition of a slum that this paper adopts. With the above characteristics, slums have been described as one of the world's most life-threatening environments [4]. All the foregoing precarious conditions 
pertaining in slums are what has provoked much discussion about their existence and how to deal with them, i.e. the "slum-free" versus "slum-friendly" debate. In dealing with slums also considered as squatter settles, the simplistic approach of governments has clearances without feasible resettlement offer for the displaced who are also legal citizens of the nation. Recent examples of such are the case of Sodom and Gomorrah in Accra [20] - the national capital city of Ghana and Abinkyi slum in Kumasi [21], the Ashanti Regional capital. Such moves have however received much banter from human rights advocates [22] who recognize the need to provide for the fundamental shelter needs of the urban poor. With the foregoing simplistic approach of the state, governments seem to remain clueless as to how to deal with slums which are not squatter settlements. Such slums resulting from the haphazard development of originally planned settlements due to a phenomenon that has been simplistically termed as the 'urbanization of poverty'.

The central problem this paper seeks to address is the fact of the continual existence and worsening condition of slums, perceived as urban low income neighborhoods in spite of attempts of governments at dealing with the problem of slums. The seventh millennium development goal of the United Nations, which deals with environmental sustainability, has as its 11 th target the achievement of a significant improvement in the lives of at least 100 million slum dwellers by 2020 . To attain this there is an obvious need for the redevelopment of slum areas. The question now is to what extent can a socio-economically realistic redevelopment be carried out in typical Ghanaian slum? This paper presents the findings of the investigation of how slums could be successfully dealt with in Ghana, given their socio-economic realities using a case study approach. The main aim of this paper is to examine why attempts at dealing with the slum problem has failed and to examine the proposition of regenerative redevelopment against the socio-economic realities of the typical Ghanaian slum. This paper extensively uses data gathered from Anloga-Sobolo Township in the Kumasi metropolis as a case study area.

The research questions this paper addresses are as follows:

- How eminent is the 'slum' problem in Ghana?

- Do slum dwellers recognize the insufficiency of their environments and what are their recognized needs relevant to their housing and environment?

- Are slum dwellers open to the idea of a neighborhood redevelopment and are they willing to participate in the process?

- What are the residential aspirations of slum dwellers?

- Are there laudable economic indicators that could justify the redevelopment of slums?

Moving forward, related areas which could be researched into include the feasibility of community participation in an urban management program to prevent neighborhood blights, feasibility of private sector participation in urban regeneration program and lastly, the importance of urban regeneration to sustainable development in Ghana.

\section{Approach and Methodology}

The qualitative research approach is adopted for the study presented by this paper. This approach has been described as involving an inquiry process for understanding a social or human problem, based on building a complex, holistic picture, through the formation of words and reporting of detailed views of informants, conducted in a natural setting [23]. The methodology has the ability to look at change processes over time, to understand people's meanings, to adjust new issues and ideas as they emerge and to contribute to the evolution of new theories. [24]Though this approach is sometimes faulted for the potential subjective nature of the results it gives, the use of empirical data to support analyzed data from literature helps ground the results of such study.

This study starts with a detailed review of literature on subject area to establish the eminence of the central problem and to identify the theoretical framework relevant to the research objectives to help focus the research plan and hypothesis. Literature reviewed is analyzed alongside empirical evidence in the Ghanaian contest gathered from observation and industrial experience to establish the applicability of the theory and scenario it posits.

This is followed by the analysis of empirical data from a case study area with reference to theoretical framework and hypothesis to come to the conclusions of this paper. The employment of the case study approach was to allow the attainment of grounded results from a detailed enquiry into a singular slum to meet the objective of the study presented by this paper.

\subsection{Choice of Case Study Research Approach}

The case study research method has been defined "as an empirical inquiry that investigates a contemporary phenomenon within its real-life context; when the boundaries between phenomenon and context are not clearly evident; and in which multiple sources of evidence are used [15]. The case study approach has been championed as having many advantages including the fact that the examination of the data is most often conducted within the context of its use [15], that is, within the situation in which the activity takes place and variations in terms of intrinsic, instrumental and collective approaches to case studies allow for both quantitative and qualitative analyses of the data [16]. However the major advantage that led to its choice for this study is the fact that it allows a detailed qualitative account which helps both to explore and describe the data in real-life environment and also to explain its complexities [17].

The case study approach has often been criticized for a number of reasons. First is the criticism of the possible lack of rigor as the researcher may allow equivocal evidence or biased views to influence the direction of the findings and conclusions [15]. In addressing this drawback empirical data 
from the study area were analyzed alongside other secondary information to reach the conclusions of the study, as a measure of triangulation, thus minimizing possible bias. A second criticism of case study research is its provision of very little basis for scientific generalization since use is made of a small number of subjects, some conducted with only one subject. The question commonly raised is "how can you generalize from a single case? And thus case study research is considered 'microscopic' because of the limited sampling cases [15]. To this, however, parameter establishment and objective setting of the research are far more important in case study method than a big sample size. Thus the approach could still yield very important results that could be applied with necessary variations in different settings. Thus the deductions from this study could well be applied to the central problem of slums nationwide, with necessary variations as appropriate.

\subsection{Sampling, Data Sources and Methods of Collection}

The empirical data was sourced from primary data collected for an academic research[25]. This was basically collected from the inhabitants of the case study area and institutions within the metropolis with a stake in land development and city management. The data gathered from the case study area was done in two stages - a preliminary field survey in 2009 and the main field survey in 2010. The preliminary field survey was a recognizance one aimed at establishing the current development and environment status of the case study area to affirm its slum position as defined by UN Habitat. Data gathered during the survey was by observation and recorded with photography and short notes. Information gathered included various kinds of land uses, the general architecture of houses, sanitation and drainage situation and general development pattern and plan of the neighborhood. All this data were found useful for the discussion of this paper. Convenience sampling [19], was used during the preliminary survey per the records of the source thesis [25].

The collection of data during the main field survey was mainly done by using institutional interviews and a structured questionnaire. The interview covered government institutions with a stake in the physical development of the township. The institutions dealt with included the Town and Country Planning Department, the Kumasi Metropolitan Assembly and the Building Inspectorate Division of the submetropolitan area. The major group of people interviewed during the survey was the inhabitants of the township.

Based on the above sequential approach to data collection, a total sample size of 180 inhabitants were covered; comprising 120 (tenants) and 60 (landlords) through the application of quota sampling. Three (3) relevant institutions were also covered. The SPSS statistical package was utilized in the data analysis focusing on descriptive statistics. The qualitative analysis of data gathered by observation, open-ended questions and from literature was done with logical deductions and descriptions supported by images where appropriate

\subsection{The Case Study Area- Anloga-Sobolo}

The choice of the case study area was influenced by its very poor environmental conditions and development status (which has often made local news), its history, location and economic importance. Location wise, the township lies along the major highway leading to the central business district of the metropolis which also links the city to the national capital - Accra. Thus, the land occupied by the township could be well considered as prime land with great development potential. Historically, a group of Ewe migrants acquired the land as a grant from the traditional authority (the Amakom Stool which holds the allodia title). Thus, the town is a typical "settler settlement" with legal interest in the land they are occupying. Thus usual approach of clearance based on the status of inhabitants as "squatters" would be a difficult argument to advance. Economically, the area is noted as being the hub of some local industries supplying popular processed foods such as gari and palm oil for the metropolis. In terms of urban development, however, the area is noted as deprived with overcrowding, poor housing facilities and haphazard developments giving rise to poor environmental conditions that compromises health. The area thus qualifies under the definition of the UN Habitat as a slum, justifying its choice as a case study.

\section{The Eminence of the Slum Problem}

Slum creation is directly associated with urbanization which seems to be a barometer of human progress through the $21^{\text {st }}$ century. The annual urban growth rate in Sub-Saharan Africa including Ghana is recorded as almost 5 percent, twice as high as in Latin America and Asia. The region also has the world's largest proportion of urban residents living in slums, which today is home to 72 percent of urban Africa's citizens representing a total of some 187 million people. As more and more people seek a better life in towns and cities, the urban slum population in Africa is projected to double every 15 years in a process known as the urbanization of poverty [5].

Ghana is one of the worst affected sub-Saharan African countries with its urban dwellers forming about $51.5 \%$ of its close to 25 million population [6]. It is estimated that about $70 \%$ of Ghana's urban population live in slums [7]. As a rapidly urbanizing nation, the urban population has almost doubled what it was in $2000(8,856,000$ urban dwellers) as against 2010 (12, 811,000 urban dwellers) [6]. Yet, the majority of new urban dwellers will find themselves living in more severe slum conditions as time goes on and the slum problem is left un-tackled with the seriousness it deserves.

Beyond urbanization, the existence of slums has been blamed on the lopsided and vested land policies covering land ownership, infrastructure provision and maintenance, and other socio-economic issues [8]. In Ghana the land 
question is a convoluted one. On the one hand is a strong traditional sector for the control and management of land for about $80 \%$ of the country's land mass and this is given constitutional backing. On the other hand is a state ownership and control of the remainder of the $20 \%$ of land, yet land policies and legislation by the state have to be national in character, resulting oftentimes in conflict between traditional leaders and state land management machinery [9]. It is therefore not surprising that state land use planning machinery for development control is notoriously weak in implementation, explaining the rise in haphazard developments nation-wide. This has been the state of affairs, and notwithstanding the implementation of a World Bank and other international donor supported Ghana land Administration Project (GLAP I \&II) since 2003; the nation is yet to achieve a harmonization of customary land governance rules, regulations and law with statutory legislation on land in the form of concrete and finalized Land Use and Spatial Planning Bill and Lands Bill to be passed by Parliament into laws. From the foregoing, it is important to note that, the diversity of land related problems in the country result from a complex combination of historical, political, social, environmental and institutional circumstances that differ by location; an underpinning of the importance of home grown solutions.

Thus for the urban poor, slums are a solution representing a trade-off between - poor living quality and close proximity to jobs and markets; poor quality of houses and low affordable investment in housing; no housing and tenurial insecurity; no access to infrastructure and informal and intermittent supply of urban services. Whatever is responsible for the creation of slums, their continued existence cannot be pardoned, for apart from their internal precarious conditions their existence has repercussions on the whole urban region in which they exist. Such repercussions, which could be summed up as social, economic, environmental and political challenges, draw back the socio-economic development of the nation as a whole. At the center of the disdain for their existence is the fact of compromised sanctity and dignity of the human lives that have the slum as home [10].

\subsection{Approaches to the Slum Problem in Ghana and the Sustainable Proposition}

Given that the conditions of slums are undesirable in the urban region for obvious health, aesthetic and moral reasons, governments, non-governmental institutions as well as international organizations have all shown keen interest in dealing with the problem of slums in the country. Many who cannot imagine the eradication of slums, given the historic record of failed attempts at dealing with them have often met the discussion of how best slums could be dealt with skepticism. Varied efforts have been made by governments over the years to deal with slums. In the sixties, governments acknowledged the existence of slums but did little about them. However, between the seventies and nineties, the attitude of governments changed, as there was a show of aggression and taking of direction in dealing with slums in Ghana. Demolitions and evictions with and sometimes without replacement, resettlement or relocation were carried out. Sites-and-services with aided self-help (tenant provides labour) were launched by governments; slum upgrading programmes were also embarked on; enabling approaches (to promote good housing development) as well as the granting of security of tenure were also tried by governments [11]. Despite all outlined efforts, slums still do exist with projections of increased growth and seemingly no hope of eradication.

As pointed out by Geoffrey K. Payne in his book Urban Housing In The Third World [12], such failure could be blamed on the fact that the inherited or imported concepts evolved in western world but do continue to be widely regarded as valid frameworks for pursuit of development strategies even though their effect when translated into policies is often counter-productive. This is because the socio-economic realities of the countries (of application, i.e. developing countries) are very different from that of the industrialized west. Particularly in dealing with existing slums, slum clearances in pursuit of westernized development plans has proved a futile exercise that only uses up scarce resources to actually increase the number of people needing shelter, thereby intensifying the problems such policies were intended to relieve. In addition, the active intervention of NGOs and international organisations has led to increased knowledge and affinity with the lives of slum dwellers making demolitions politically not feasible. The way forward in dealing with existing slums is the redevelopment of such settlements, based on strategies which judiciously apply the elements deduced from settlements which are the product of indigenous social and economic systems. These even though they may be described as 'archaic', offer climatically appropriate and technically sophisticated solutions to urban planning problems [12]. These elements, which may be contrary to certain western principles of development planning, are outlined by Payne as high density, mixed land use, variety of plot sizes and local control over housing provision. The economy and flexibility of planning frameworks that exploit these elements could ensure the use of urban lands to their full potential within economic constraints and this approach is suitable in the Ghanaian slum redevelopment context.

In recent years, there has been an increasing realization of the need to pursue urban redevelopments with emphasis on partnership working, community involvement and sustainability. Such process termed as regenerative redevelopment is directly contrary to the fundamentally modernist, state-led tendency towards site assembly and comprehensive redevelopment often termed 'slum clearances', earlier on promoted and pursued by governments the world over especially in dealing with slums [13]. Regenerative redevelopment therefore involves the gradual redevelopment of a slum neighbourhood to accommodate its inhabitants within same location but with 
better housing and environmental conditions, creating a "slum-friendly" environment.

In support of the slum-friendly idea, it has being well argued that in the midst of urban housing famine, 'there is nothing that slum clearances can accomplish that cannot be done more efficiently by an earthquake....Demolition without replacement intensifies overcrowding and increases shelter cost. It may also increase squatting and thereby create slums that are more stubbornly enduring than those removed' [14]. Regenerative redevelopment is thus a feasible slum redevelopment tool in the context of resource constrained economies of the developing world. Indeed, in discussing the failure of such slum clearance policy in Singapore, Abrams [14] noted again that 'If this type of policy cannot be executed successfully in the context of relative prosperity and low population growth prevailing in Singapore, it is hardly likely to be valid in situations of low per capita incomes, scarce resources and rapid urban growth'. The latter description aptly fits the case of Ghana, which is why slum clearances should not be a choice for Ghana.

\subsection{The Story of Urban Housing and Regeneration in Ghana}

In Ghana, all cities have sections of their residential neighborhood which are very deplorable state and yet inhabited by a good section of the populace usually considered as within the low income bracket. Housing Estates developed the State Housing Company Limited across the ten regions of the country has not been spared this phenomenon. Established in 1956 as a government housing Corporation with the aim of providing affordable residential units to majority of the urban population of the country, the company over the years developed over ninety-three (93) urban estates nationwide with over 32,000 housing units. These were mostly sold on leasehold basis and $\mathrm{h}$ a few held on rental. Thus a good proportion of the residential urban Ghana falls under the management of the now State housing Company Limited.

The phenomenon of urban decay is very glaring in most housing estates nationwide; thus its inability to boast of a first class residential estate in some regions such as Takoradi. Much of its estate sprawling over prime urban lands are described as $2^{\text {nd }}$ and $3^{\text {rd }}$ class neighbourhoods, with a good number more of a slum. Following are pictures depicting this squalid situation of low income State Housing estates: Source -North Effiakuma Estate - Takoradi ( October 2015)

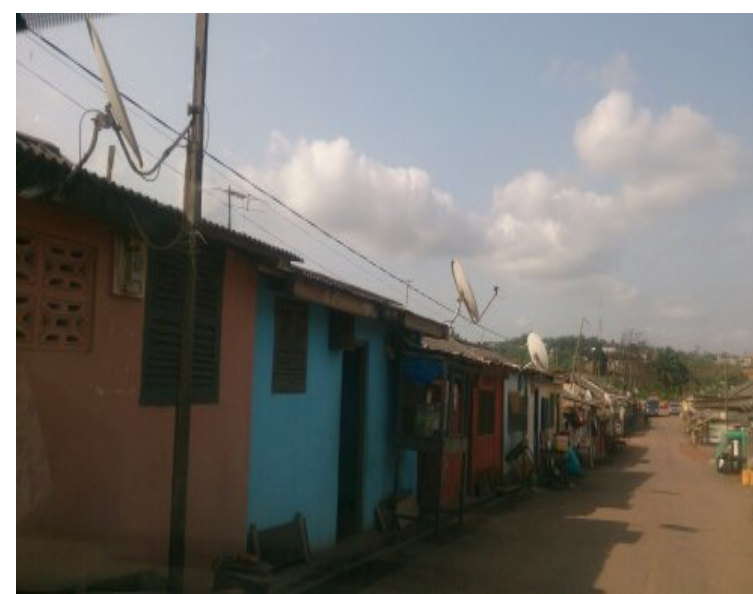

PICTURE A

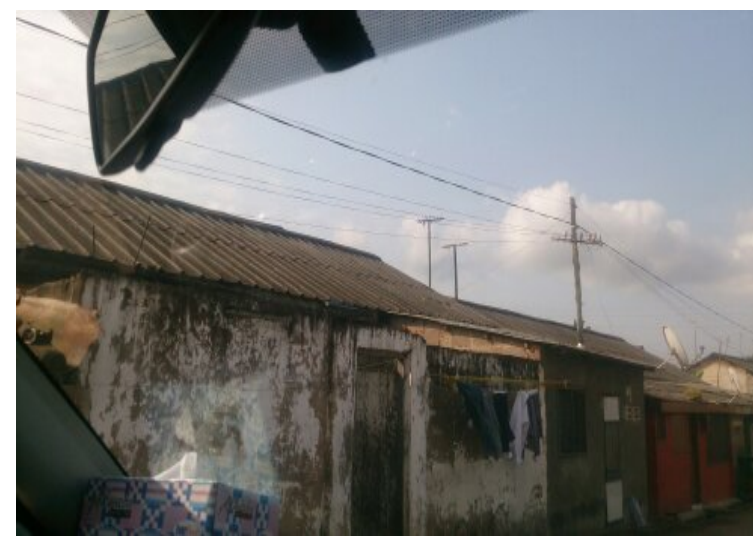

PICTURE B

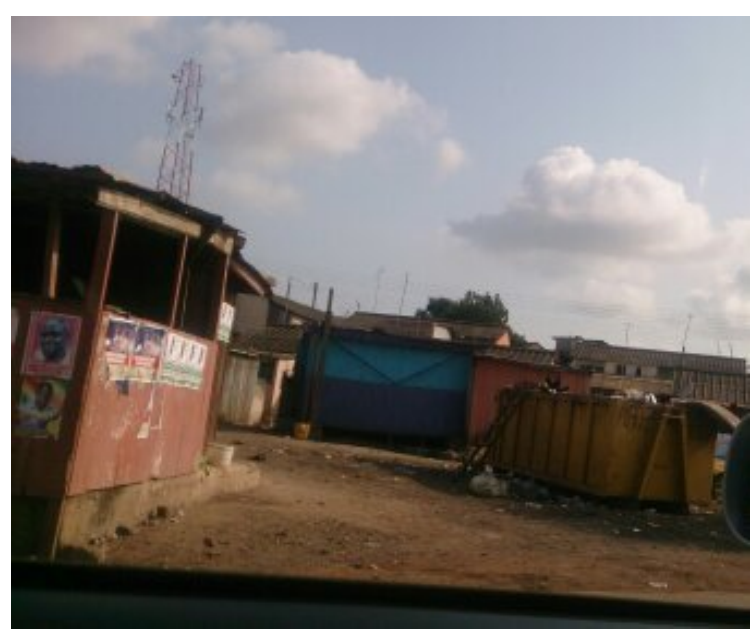

PICTURE C 


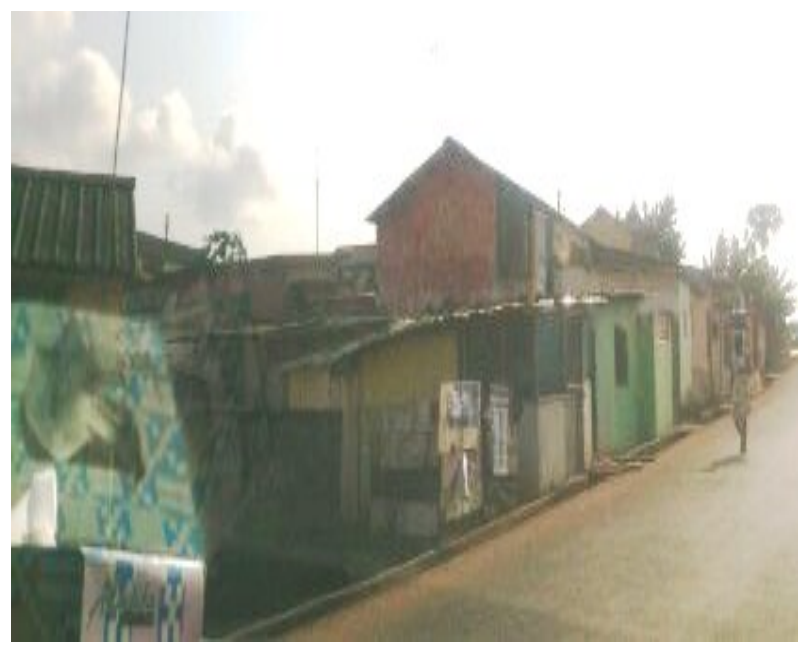

PICTURE D

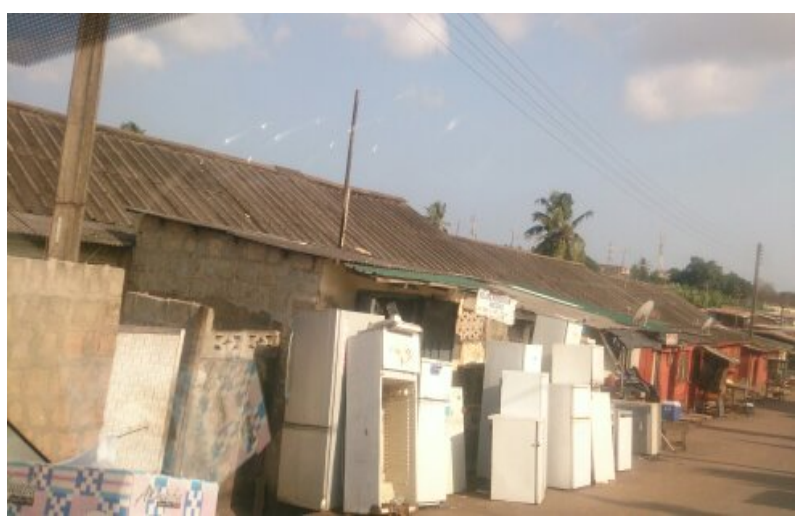

PICTURE E

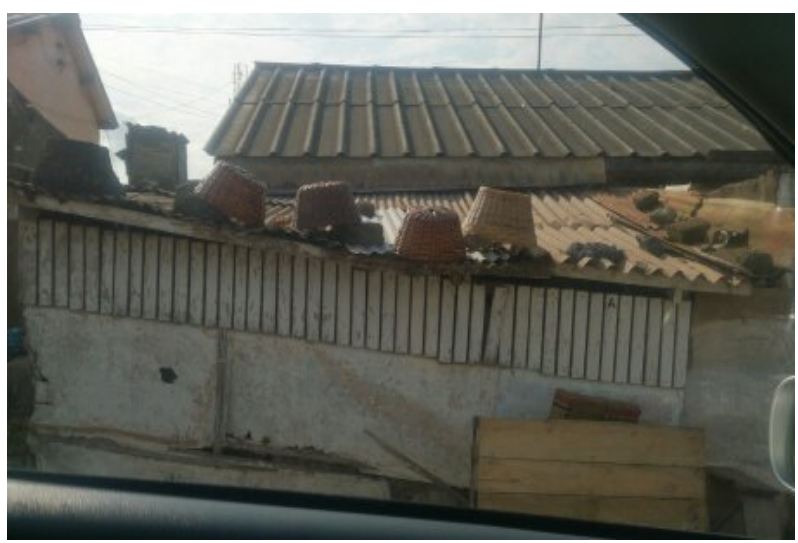

PICTURE F

The squalid state of the early State Housing Estates occupying now central urban residential areas and the need to provide more housing for the majority low to middle income working group without a further costly urban sprawl led to the urgent call for regeneration. The picture below depicts the first regeneration plans of the company:

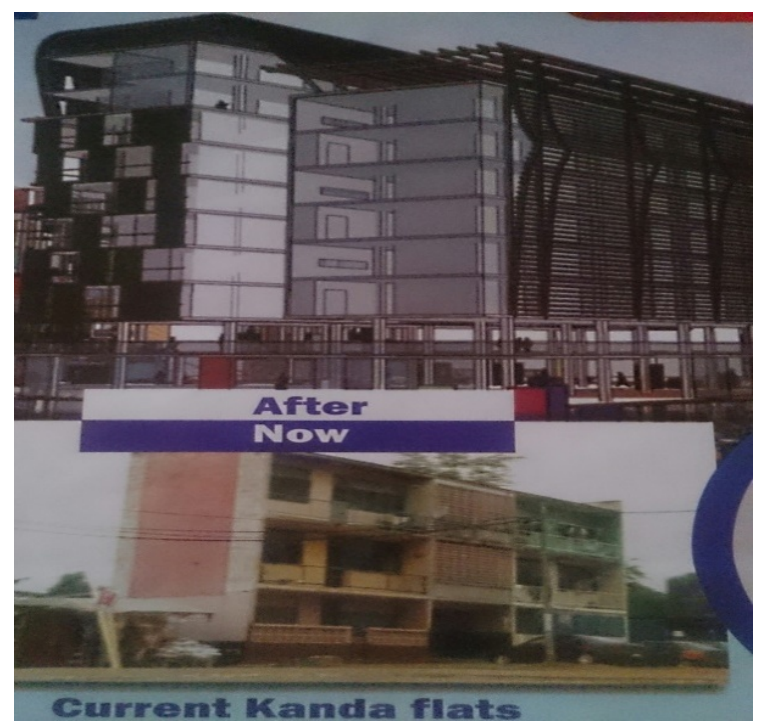

PICTURE 3.7

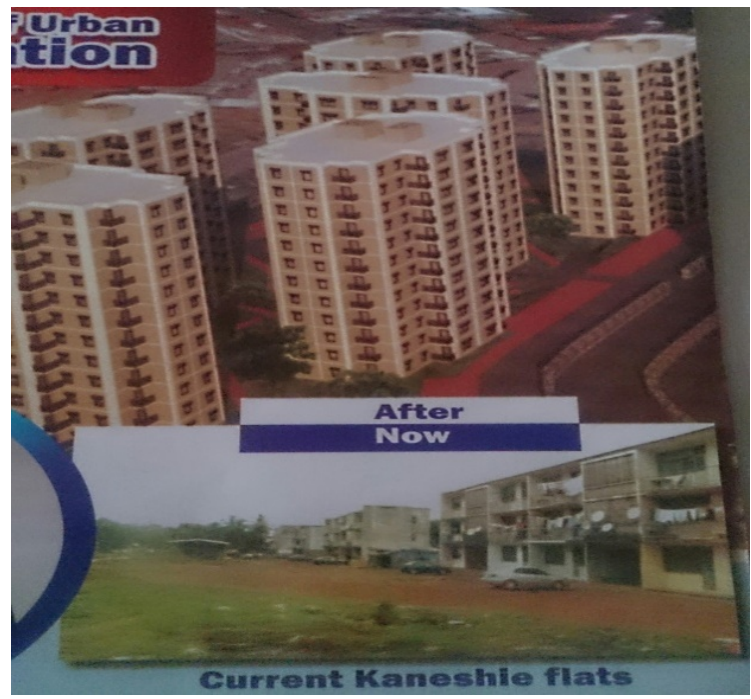

PICTURES 3.8

Regeneration efforts planned and started in the Accra (the capital city with oldest and largest SHC estates) in 2013 was frustrated by the residents of the estate first tackled with a court action which they finally lost. A major lesson derived through the process was very much same as was captured by the TAMSUF report which is - "In handling communication with inhabitants being affected, it should not be assumed that what are discussed and agreed with leaders of cooperatives have been communicated to the other cooperative members. Staffs used for such interaction should stay long enough to ensure consistency in communication on the project". It was realized that though the leaders of the affected inhabitants very well appreciated the project and its intent, the rest of the inhabitants were poorly informed, fuelling a mistrust about 
the intent of the project. The initial data collection stage handled by trained service personnel whose service mostly ended within a year was also not helpful. Finally the development investment sourced for the project was lost due to the protracted wait on court proceedings causing a frustration of the project.

The action of the residents who were to benefit from the project and its subsequent impact leads to the need to critically consider the socio-economic feasibility of regeneration in Ghana.

\subsection{The Hope of Tamsuf's Success Story}

The socio-economic feasibility of the regenerative approach to slum redevelopment has been proven through the experiences of the now developed world such as the Great Britain (from the early years that followed the First World War), developing countries like India and through a recent pilot program of the UN Habitat and in Ghana within the Ashiaman Municipality[26]. The recent UN- Habitat pilot project as part of efforts at achieving MDG 7- target 11 had economic feasibility as its key objective. Carried out under the Slum Upgrading Facility (SUF) the project's primary objective was thus to develop, test and apply new and innovative means of financing pro-poor urban development with a strong emphasis on the mobilization of domestic capital. Popularly known as the TAMSUF project, (spanning the period of 2004 to 2011 from planning to evaluation) successfully developed 31 dwelling units and 15 commercial shops with a commercial toilet and bath facility for use by residents in the area within the Amui Djor slum enclave in the Ashiaman Municipality. Each unit consisted of a Hall and Chamber measuring with a separate kitchen facility. Each unit is approximately 18sqm in floor area. Pre-financed by SUF, the financial burden of the project was successfully turned over to the benefiting slum dwellers who are making payment through a cooperative credit union. The introduction of commercial units into the project worked to cross subsidize the cost to the beneficiaries and improve the economics of the project. The ready acceptance of the project by the slum dwellers also goes to foster the social feasibility of the project and this is a model worth replicating in other slum areas of the country.

\section{Socio-economic Characteristics of the Typical Ghanaian Slum and Its Opportunities for Regenerative Redevelopment}

Anloga- Solobo, a township situated in the Kumasi metropolis with all the characteristics of a slum was investigated as a case study to aid conclusions on the central theme of this paper. Discussed below in this section are the physical and socio-economic realities of the neighbourhood and its opportunities for regenerative redevelopment as posited in literature reviewed [25].

\subsection{The Geograhy}

\section{Locational Map of Anloga-Sobolo}

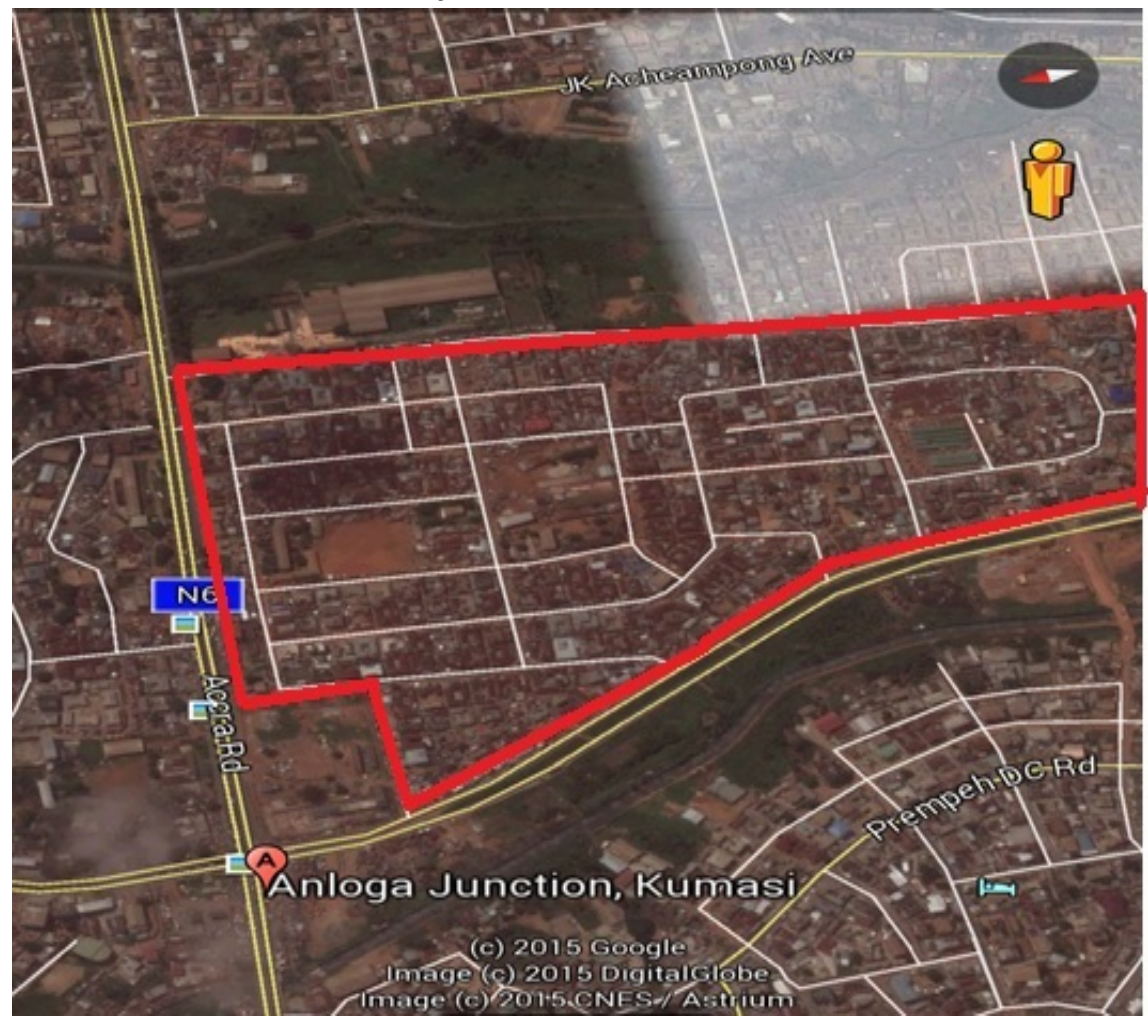


The Anloga-Sobolo township formally known as Oforikrom Extension is bounded by the major Accra-Kumasi highway to the east, the Asokwa Township to the north, the Susan River and the Susanakyi township to the south and Old Ahinsan Estate to the west. The location of Anloga-Sobolo in the Kumasi metropolis gives the land area covered by the township tremendous latent value that could be well harnessed with a redevelopment of the area. In its present state, the total land area of the township is covered with developments with no space for the provision of any of the social amenities so much needed by the community. However, a redevelopment that would seek to organise land uses and make use of vertical space could help free much of the prime land covered by the township for other compatible and lucrative developments, allowing the realisation of the latent value of the township's land. As in the case of TAMSUF where the vertical redevelopment of the residential space occupied by families allowed the provision of prime commercial space to help defray the cost of regeneration sought and thereby making it sustainable, Anloga-Sobolo could be redeveloped in a similar scheme. In fact, the case study area has a greater potential as the serenity of the townships bounding it could allow the redevelopment of the freed space for institutional use as well which would have its positive ripple effect on the state of the community.

The land area of the township is undulating, with some flood plains in areas bounding the Susan River. The vegetation cover of the area is almost non-existent, as the whole area of the township has been affected by (much uncontrolled) human development activities. The perennial flooding is a major predicament of the township of that has drawn attention to the poor state of development of the township. A redevelopment of the township which will harness the latent value of the land area of the township (as afore discussed) would warrant substantial investment into infrastructure which take care of drainage to avert such flooding. Also following the garden city concept of the metropolis, provision for vegetation cover within the township's redevelopment plan would very well improve the comfort, health and economic value of its neighbor.

\subsection{Brief History}

The land area of the Anloga Township was given as a grant by the Amakom stool (of the Kumasi) to the early Ewe migrants. The area was demarcated and named Oforikrom Extension by the then town planners. As an extension of Oforikrom (an existing town), Anloga was expected to share the Oforikrom's community resources. This planning decision however seemed not have taken into account the future expansion of the township with population increases. The settling of other migrant tribes and nationalities in addition to natural population growth by births in the area over time highlighted the problem of lack of public amenities in the community. This history of the acquisition of the land occupied by the township clearly makes known that the settlement is not a squatter settlement. The settlers were given title to the land they occupied as per native customs. The consideration of the land rights of the homeowners is thus key in any form of redevelopment agenda. The development of systems that would preserve the land rights of homeowners in the phase of redevelopment would be key in attaining their support for any form of redevelopment agenda. This also cancels out the unpopularity of slum clearances warranted mostly by the fact that squatter settlements do not fit into the comprehensive development plan of the area in which they find themselves. Thus, the regenerative approach in correcting the ills of an originally planned settlement would be the best approach in dealing with the slum problem.

The early settlers started development of housing units typically in rows. However, the rapid expansion of household sizes due to in-migration and births led to the unauthorized extension of houses and the popular development of attachments (which could pass for shacks given the poor materials used in their construction) to the houses. This in addition to the lack of sufficient infrastructure to meet the growing needs of the population has led to the settlement's present state of a slum. This bit of history also tells housing provision in the neighborhood has been solely dependent on private effort. Given the generally low income of its inhabitants, the resulting development (considered poor) is obviously their best response to their fundamental need for shelter. A consideration of the housing needs of these urban 'poor' and provision of technical and monetary subsidy for its development would have gone a long way to avert the present slum conditions.

Efforts at developing the amenities in the area took a more serious turn in 1998 under the Urban 4 project of the reigning government then. The efforts of the central government even though went a long way to open up the neighborhood, lifting it from its very deplorable state and bringing it closer to its urban environment, was a piece meal attack at the issue of sustainable housing for the urban poor due to resource constraints. The weakness of this effort of the government (despite its immediate good response) is seen in the fact that these facilities are going down the drain with no maintenance system in place and the relevance of their provision is coming to zero with constant population increases.

In recent time, a major metropolitan development that has been having an impact on the development trend of the area is the Ring Road Development project. This has led to the evacuation of the wood workers who were the major economic sustenance of the township to a new wood village. This movement has sparked speculations of reduction in the economic vibrancy and wellbeing of the township. There have also been speculations of possible reduction in the population of the township with time given the movement of the wood workers from the vicinity. However, from a planning and environmental point of view, the movement of these wood workers is very good for the preservation of the sanctity of the residential character of the town, thereby improving its redevelopment potential. This is because the movement of these wood workers has rid the township of 
both air and sound pollution, and has eliminated the need to provide for conflicting industrial activities in any planned redevelopment scheme. More lands that are valuable have thus been freed and the neighbourhood has been brought further closer to its urban region. Picking up an internal regeneration agenda would therefore be very congenial to this background.
Anloga-Sobolo has closely developed residential units, permeated by access routes. The buildings have a form of linear arrangement, closely delineated by main access routes that are in quite good motorable state. The buildings within each row are however haphazardly placed with the main entry into many buildings hidden in corners between buildings. The spacing between adjacent buildings is very poor and almost non-existent in cases where building extensions and local economic ventures have taken it up the space. Picture 1 below shows the state of the area's physical development.

\subsection{The State of Housing and Environment}

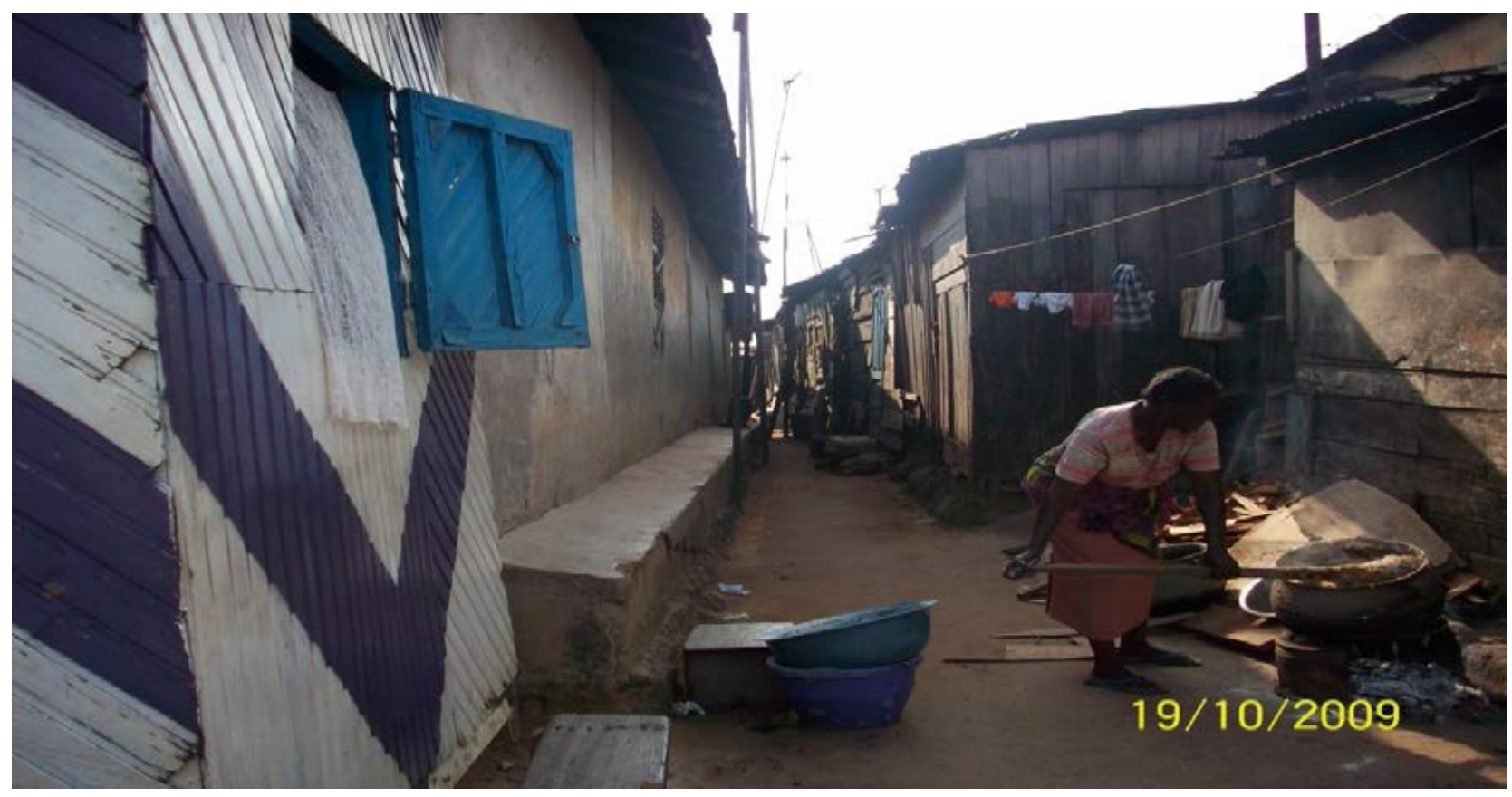

Plate 1. typical access route between residential units of Anloga -Sobolo, crowded by wooden structures and activity

Access routes between buildings within rows are also mostly badly affected by erosion and crowded. This is depicted by plates 2 and 3 below.

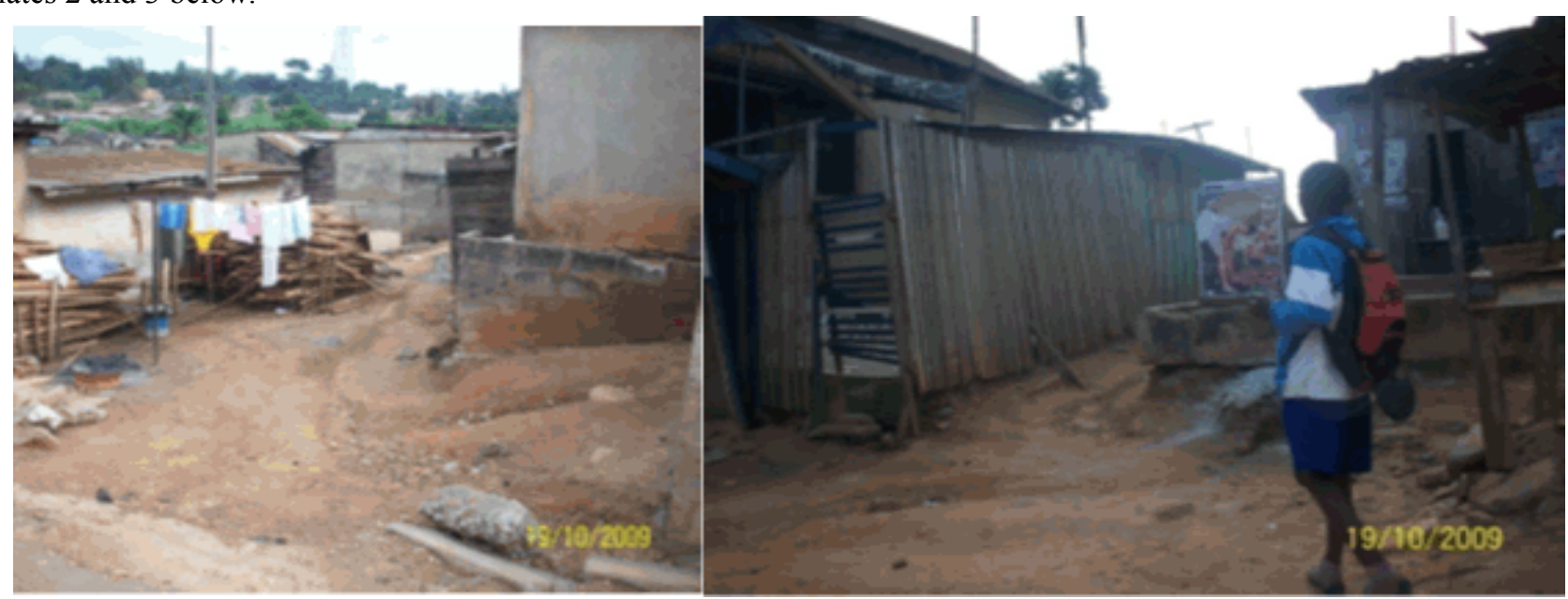

Plate 2. and Plate 3. Poor Access routes in Anloga -Sobolo

This state of physical development is very precarious as it undermines the fire safety of the neighbourhood and ventilation in the homes. In addition, building extensions have been stretched to the edges of main roads leaving no reasonable space between people's homes and the main road. One could typically find the home activities of certain inhabitants stretching onto the main road. Picture 4 below depicts this: 


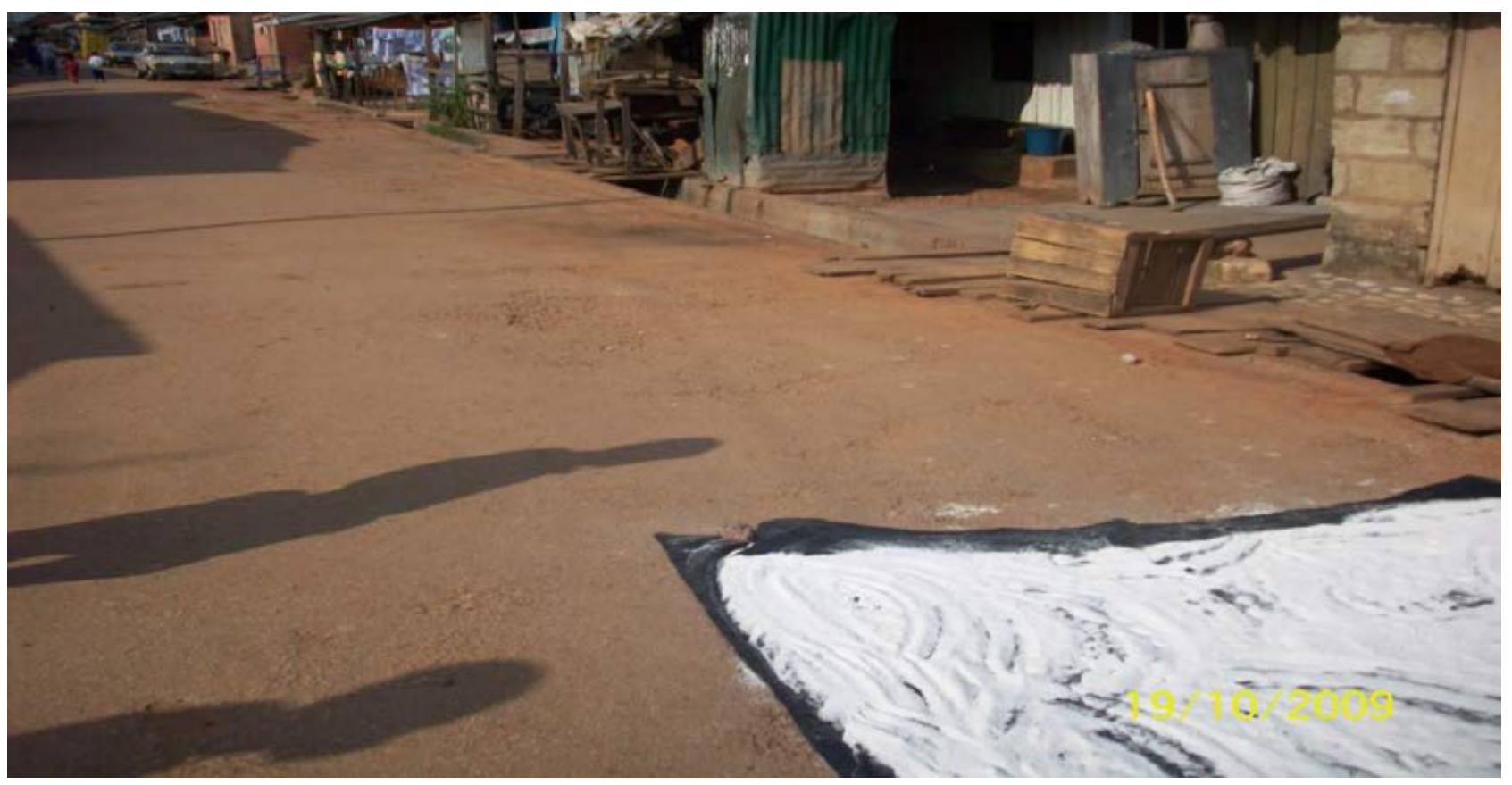

Plate 4. A row of residential units extended onto the edge of main concrete drain of main access route. Right-hand corner of picture showing the drying of a family's corn flour on the main access road

The nature of residential accommodation particularly affects pedestrian safety and impedes the movement of vehicular traffic in the neighbourhood. It is also worth noting that what can be perceived as unauthorised extensions to houses, are the response of the people to their increasing shelter and employment needs within the limits of their income and technology available to them. Thus, a redevelopment agenda by an external body that only seeks to demolish or clear away these extensions without consideration of the needs of the populace that have been neglected is likely to be met with strong opposition from inhabitants. Any form of redevelopment should therefore identify the needs these extensions serve and seek to provide alternatives that address same needs in a more "slum-friendly" manner.

The residential units of households surveyed were mostly of the compound house architecture (84.2\%). These compound houses have an average of 15 rooms, with some houses however having as many as 38 rooms all rented out to families. The compound house architecture obviously allows high occupancy rate, allowing the community to accommodate its relatively large population at minimum cost. Thus, occupancy per house realized during the survey was as high as 77persons in some houses, and averaged 30 persons in most houses. Consequently, the stress on the town's environment could be well explained by its high population density. These compound houses are mostly built with a combination of local and modern building materials $(83.8 \%$ of households surveyed). This is a good indicator of the kind of housing that could be afforded by the populace of that community as against what the formal building standards demand. A similar architectural fashion in the Ashiaman area that informed the kind of redevelopment that was successfully provided by TAMSUF as discussed in section 2.2 above. This corroborates Payne's [12] suggestion that redevelopment schemes keep to plans that are realistic to the socio-economic realities of townships affected.

Some recent building extensions were of sandcrete block work, but these were mostly unfinished and reflection of the resource constraints factor that compels home owners to combine modern and local building materials in their home construction efforts. Building extensions mostly consisted of wooden and aluminium roofing sheets. See Plates 5 and 6 below:

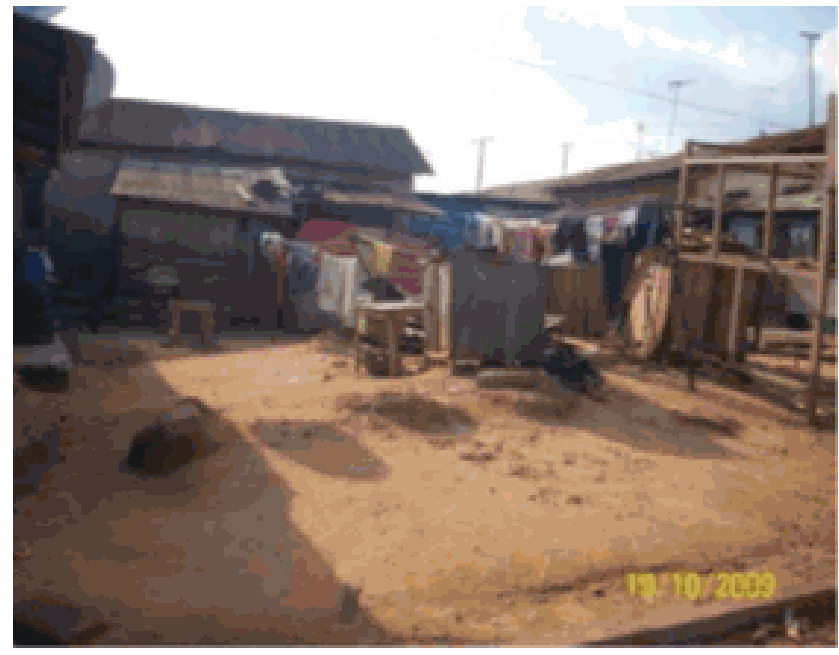

Plate 5. An incomplete compound 


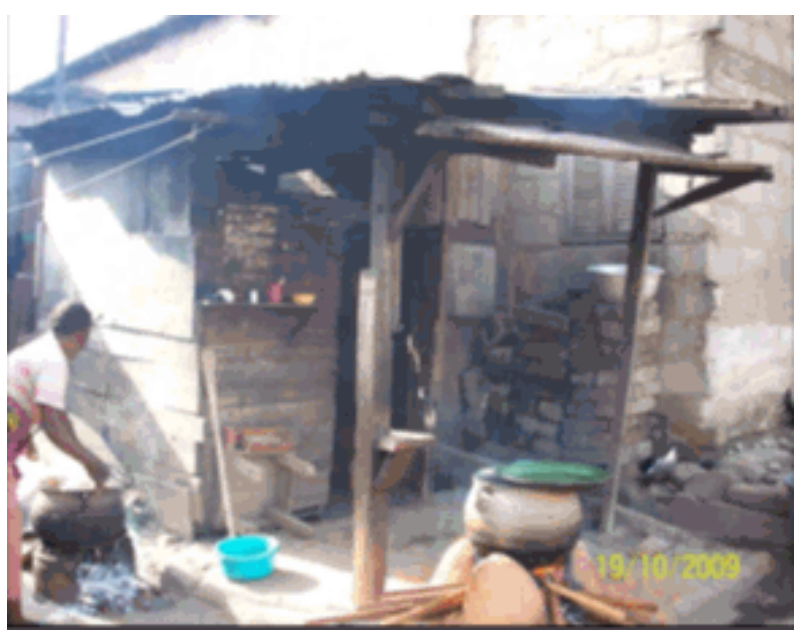

Plate 6. unfinished home with wooden building extension

Most rooms within the popular compound house units in the area have poor lighting and ventilation. These generally consisted of single window openings, which are sometimes covered with plastic material due to lack of proper window systems. The implication of plastic material on proper ventilation is obvious. Picture 7 depicts this:

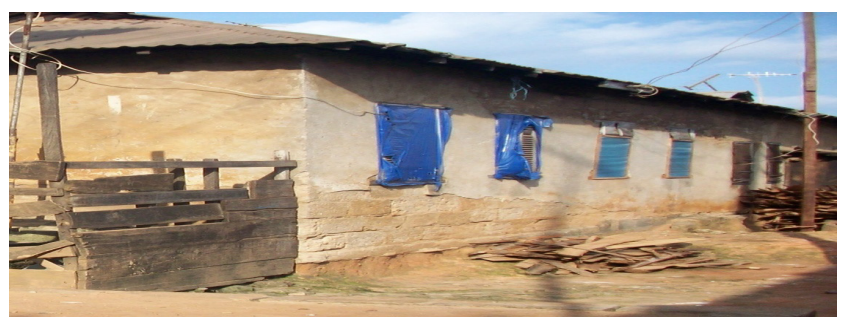

Plate 7. A residential unit in Anloga-Sobolo with plastic covering window area

Commercial activities of various kinds front and intersperse most residential units bounded by main access routes. This again supports Payne's [12] theory of developing mixed-use neighbourhoods as against the conventional segregation of uses. This is key for any redevelopment agenda as proximity to place of employment is very important to the urban poor, for reason that their incomes cannot cater for additional transportation cost to most parts of the city for their needs to be satisfied.

Over $90 \%$ of residential units surveyed are in very poor state of repair as depicted in Pictures 8 and 9 below:

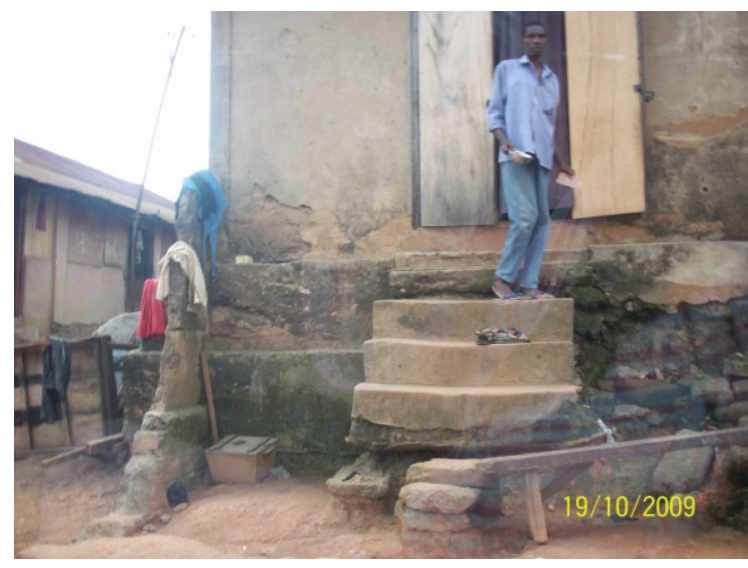

Plate 8. Dilapidated residential unit

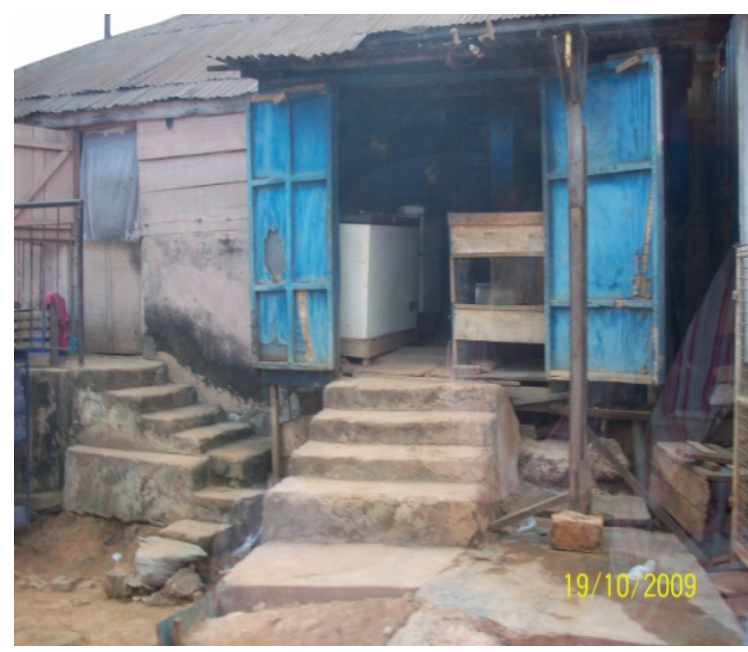

Plate 9. Dilapidated residential unit

This is an indicator of either the general insufficiency of the rent income received by property owners, their overdependence on such income for personal upkeep or the lack of prioritising of necessary maintenance work in the use of rent incomes. That maintenance in not a priority was explained by the family ownership of most of the properties and also a seen as a general attitudinal problem in the Ghanaian society with even individual ownership. Any redevelopment agenda should have within its remit a provision for a management body that would be responsible for the maintenance of properties and infrastructure provided. Their operations could be supported by a services tax system. Any form of re-housing left to the mercy of their low-income beneficiaries with no external management body would only degenerate leading to a waste of the initial capital invested. 
Drainage in the township has been helped by the major concrete drains constructed during the construction of feeder roads in the area. However, drainage systems within rows of houses and other open areas is very poor leading to the creation of very unhygienic conditions. Pictures 10 and 11 below depict this state of the community.

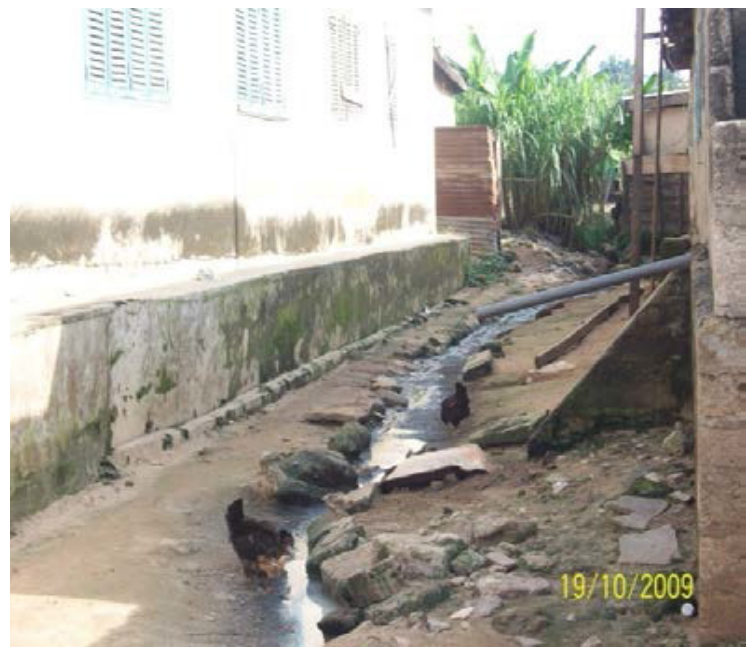

Plate 10. Poor drainage between

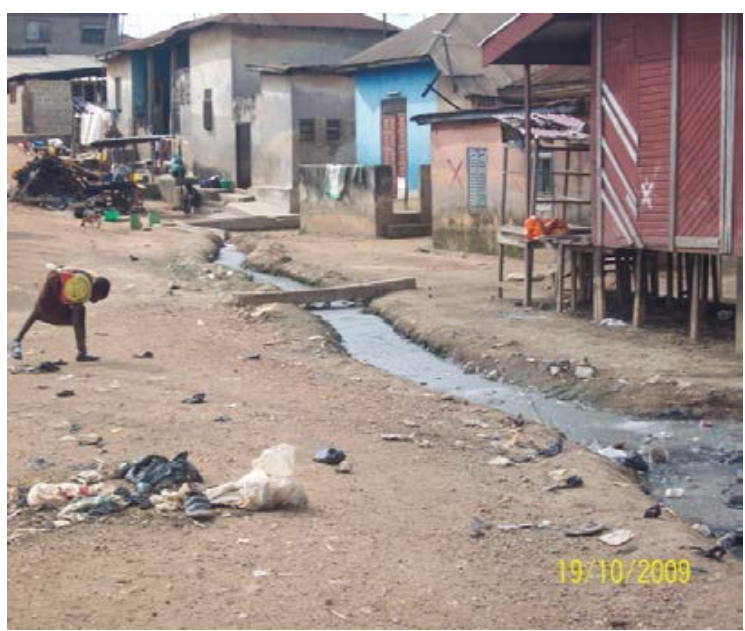

Plate 11. Poor drainage in front of

Areas closer to the water body bounding the township (and thus liable to flooding) are invariably used to indiscriminately dispose of waste and local industrial activities. However, the waste and unhygienic environment created in the area has a direct reflection on the state of health of the inhabitants of the township and the metropolis at large. Apart from the fact that homes are located close to the area, children tend to choose the area for their play times due to the open space it provides. The workers of the local industries located there are also mostly inhabitants of the township. Lastly, local food products (e.g. gari and palm oil) from the area are sold to the inhabitants of the township and metropolis at large. Pictures 12 and 13 depict this described environment.

These very poor environmental conditions are what often trigger the simplistic call for clearances without consideration of the needs that have given rise to these environments. For example, in the national capital of Accra, on June $3^{\text {rd }} 2015$, a twin disaster of flooding and explosion at a fuel station killed some 160 people. The consequence of that disaster has been a series of slum clearances in the city to reduce the risk of flooding and environmental disasters. Such knee-jerk reactions have the potential creating unintended consequences far worse that the suffered ones. In consonance with the idea of mixed land use, provision would have to be made to cater for local industries, which are a major stay of the local community in any redevelopment agenda. Any attempt at clearance and relocation of these people and their commercial lives need careful planning and should be considered as a measure of last resort. A redevelopment agenda should seek to enhance the operations of these local industries in situ by helping not only their environment, but also their production technologies to boost their productivity in environmentally-friendly ways. This stands to positively effect on the standard of living of the populace who own the businesses and government can rake in revenue from the same through taxation

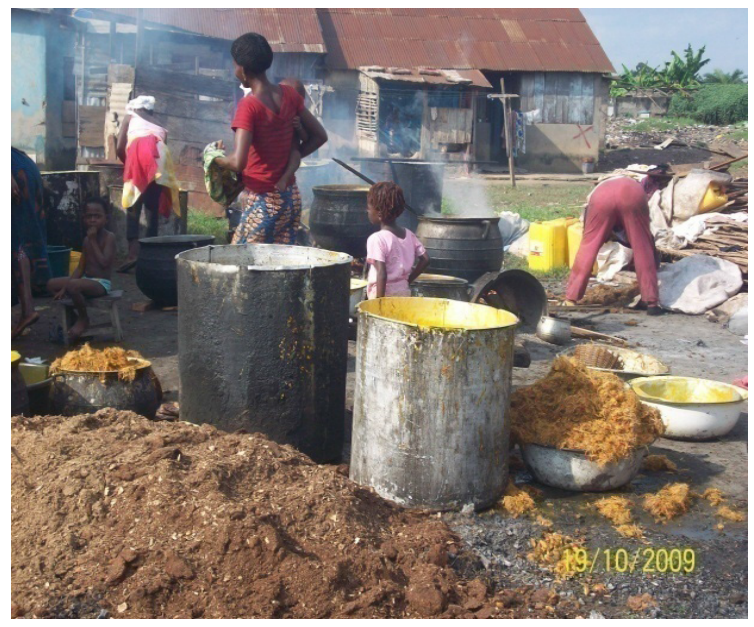

Plate12. Palm oil production facility

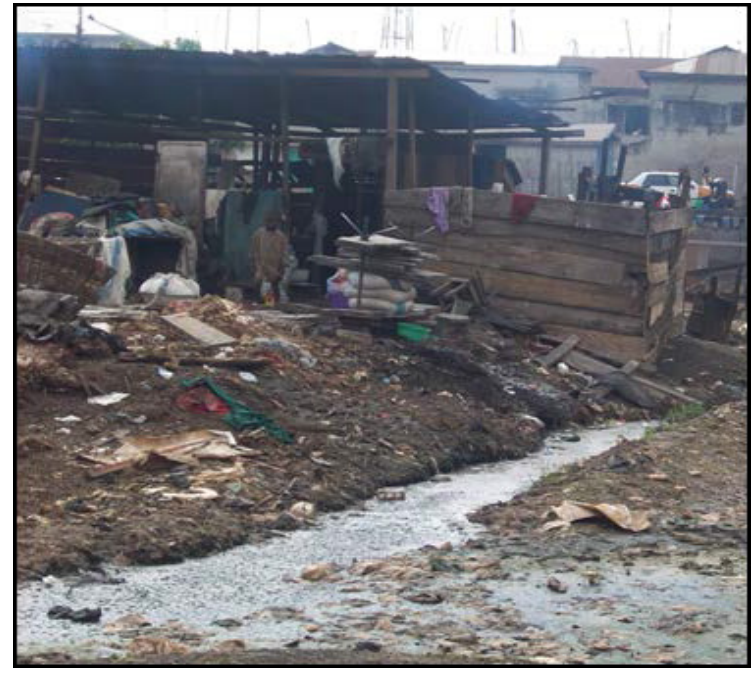

Plate 13. Gari production facility 
The neighborhood is supplied with electricity and water from the public mains. However, households are mostly poorly serviced. A redevelopment agenda would have to consider the provision of potable water from sources that involve little cost; else high cost for water scares the urban poor into compromising their health by using unsafe water for drinking and other domestic purposes. The provision of shared toilet facilities as done in the case of TAMSUF should also be considered in the case of any regenerative redevelopment in the case study area.

\subsection{The Socio-Economic Characteristics}

The foregoing description of Anloga-Sobolo gives a good picture of a typical Ghanaian slum, which unquestionably needs outside intervention. The nature of the intervention however matters a lot and must be one seen as culturally acceptable and socio-economically feasible. The township of Anloga-Sobolo though started by early Ewe settlers, now has cultural diversity just as in many other parts of the metropolis. From the survey, the various ethnic compositions were Ewes (34.8\%), Fantes (29.5), other Akan tribes (20.5\%), Northerners $(8.9 \%)$, Gas $(2.7 \%)$, and Foreigners (3.6\%).Thus, it could be said that the township has assumed the metropolitan characteristics of the city. Consequently, the architectural and infrastructural provision of any regenerative redevelopment scheme has a potential for social acceptability.

Majority of tenants (59.8\%) in the community were within the ages of 31 and $60 y e a r s, 33 \%$ between the ages of 18 and 30 , and $7.2 \%$ above $60 y e a r s$ old. Thus most tenant inhabitants of Anloga-Sobolo are within the highly productive age bracket. Also in the case of landlords/caretaker, majority $(61.4 \%)$ were within the ages of 21 to 60 . It is also worth noting that they are male dominated $(66.7 \%)$. This could be explained by a landownership system in which decision-making is male dominated as well as the economic positions of male and female in accessing home ownership or providing caretaker roles.Thus, the human resource base of the township could be considered as having a good potential to contribute to the economy of the metropolis. This is contrary to the expectations of many that slums are purely dens of crime and moral decadence with nothing positive to offer. Majority of tenants surveyed had an average of three (3) dependants with a few having as many as eight (8) dependants. Property owners surveyed had an average of four dependants with some having as many as 19 dependants. This difference between tenants and property owners' dependants could be explained by the relative economic positions they possess.

The foregoing demographic characteristics of the township (typical of most urban slums) tell the significance of the township to the productive economy levels of the metropolis and thus the nation. With a majority of its tenant and landlord population within the productive age bracket, the township could contribute significantly to the work force of the metropolis, thereby increasing its productive economy. The wellbeing (health and skills) of the township's populace also have a significant impact on the productivity of the metropolis. The high dependency ratio (also typical of most urban slums) should be an added incentive for governments to take steps to equip the working class of the urban poor to boost their productivity so they can keep undertake their responsibilities and still maintain an acceptable standard of living. A neglect of the productive potential of the working class in slums is a compromise of the standard of living of their many dependants who are part of the human resource base of the nation. Thus, the demographics of the case study area and other urban slums should be a good economic and political incentive for governments to look at their redevelopment in ways that the property rights of slum inhabitants are secured and improved upon. There is a high potential of this in the regenerative redevelopment approach as opposed to slum clearance situations.

Majority of tenants surveyed (59.8\%) were married; $25.9 \%$ were single; $13.4 \%$ separated and less than $1 \%$ were divorced. In the case of landlords, $78.9 \%$ were married; $10.5 \%$ were single; $7 \%$ separated and $3.5 \%$ divorced. That divorce was higher (3.5\%) amongst landlords than tenants (less than 1\%) was surprising as it is generally those with little or no economic power that tend to suffer divorce in marriage because husbands are unable to take good care of their wives in Ghanaian societies. Yet, it has to be underscored that divorce was generally low and not a huge concern. The popularity of marriage and the relatively low rate of divorce in the community is a good proof of the existence of a strong social system in the community. Many tenants greatest incentive for staying in the township is their establishment of good social ties in the community. This fact is supported by the relatively good security of tenure enjoyed by tenants, with some living in the same property for 29 years as found out in the case study area. Such great social cohesion and communal living is social capital that could be properly harnessed for the redevelopment of the township and its maintenance after redevelopment. Generally, the urban poor when considered individually do not have the capacity to cause the change needed in their environment - a reason for the clear hopelessness in their tone in discussing the obvious deficiencies of their environment. However, when put into cooperatives, as was the case of the TAMSUF project, they could pull together their resources and offer their organised labour and support to aid any redevelopment process.

The Anloga -Sobolo township, located in a relatively central part of the Kumasi metropolis has a relatively great economic potential by virtue of its location alone. The township had been very popular in the metropolis for its wood industry till the wood industry was recently moved to a wood village at the outskirts of the city of Kumasi.

As afore mentioned, a majority of the human resource base of the township is within the very productive age range (i.e. 31-60 years). However, the possible economic 
advantage of this age structure of the township is downplayed by the relatively high dependency ratio prevalent in the township. This situation coupled with generally low income levels due to majority involvement in subsistent economic ventures accounts for the poverty prevalent in the township. From the survey, it was realized $84.7 \%$ of tenants are gainfully employed while $60.3 \%$ of landlords are employed. The higher prevalence of unemployment among landlords could result in their over reliance on rent income for their personal upkeep and therefore low priority for property maintenance. Among employed tenants surveyed, $88.6 \%$ were self-employed, $3.1 \%$ government employees, $8.3 \%$ employed by private enterprises. Of the popular self-employed, $52.6 \%$ were into trading (mostly on a subsistent scale). The rest were mostly into artisanal and related vocations (operating on subsistent scales) such as carpentry, dressmaking, hairdressing, shoemaking, baking, gari processing, masonry and photography. Those into government employments were mostly into secretarial, teaching, security services and savings collection popularly referred to as susu for micro-finance institutions.

To ensure any redevelopment is sustainable, interventions have to be made in the employment status of the township's inhabitants given that poverty is an underlying factor for the existences of slums. In dealing with poverty, reference has often been made to issues of employment, education, health and shelter/housing. In the case of Anloga-Sobolo, the close to $90 \%$ of the township's population who are self-employed operate on subsistent basis due to the lack of the needed capital. Any redevelopment should consider the creation of a facility that would provide the local population with access to the needed start-up capital, technology and training that would enable them expand their operations to enjoy economies of scale and earn higher income. This has the potential of shifting the burden away from government as the largest employer, a position it is struggling to maintain with rising unemployment.

Generally, the population concentration in the Anloga-Sobolo and its environs makes trading activities seemingly vibrant in the township. The easy access to transportation to the centre of the metropolis and its other parts also promotes economic activities in the township. These locational and demographic advantages of the township could be well harnessed in a redevelopment scheme to make it economically viable.

Despite of the contentment expressed by many inhabitants of Anloga-Sobolo in living in the township, they nonetheless aspired to move out of the township sometime in the future when their economic positions improved. Thus, $73.2 \%$ of tenants interviewed responded yes to the question of whether they have plans of moving out of the township. This seemingly contradictory position is seen as normal of human behaviour. Thus the inhabitants saw the town as a place to live till economically sound enough to move to a more comfortable environment. Yet, the lack of long-term commitment to the township could account for the poor treatment of its environment, as there is no sense of ownership. This could be changed with the education of the town's inhabitants to instil in them a sense of community ownership and thus improve on environmental conditions.

In spite of the economic challenges of the population, they showed a remarkable commitment to meeting their present rent obligation which is a good indicator of the fact that they gave priority to their shelter needs. Rent default was as low as $6.8 \%$ with as much as $91.5 \%$ being religious to the payment of rent. $70.5 \%$ of tenants interviewed were ready to pay a higher rent if they were given homes with commensurate facilities. Thus, where their financial contribution is needed in re-housing them (as was the case in the TAMSUF pilot project) they are more likely to live up to it to ensure its success. On issue of the acceptance of government assistance for the provision facilities lacked by landlords in households, $69.5 \%$ of landlords interviewed were open to the idea. Those not open to the idea of government assistance basically had the scare of an inability to pay back monies accessed if given on loan. This is because of claims of rent payment default and meagreness of monies received as rent.

Most inhabitants interviewed reiterated the community's need for facilities such as additional public toilets, hospital, additional schools, water, refuse containers, community centre, streetlights, and improved road network. Eighty-one (81\%) of landlords and $88.4 \%$ of tenants interviewed strongly agreed to contribute their quota if the government initiated projects to provide for these facilities in their community. As to the acceptance of relocation by a redevelopment body, $73.2 \%$ of tenants interviewed were open to the idea of being relocated by government if same rent with better accommodation facilities could be accessed at their relocation destinations. On the other hand, $69.5 \%$ of landlords interviewed were open to the idea of being relocated by government if only it was a matter of compulsory acquisition of their properties. The reluctant openness of property owners to the idea of relocation seems to have been fuelled by some hopelessness in their inability to resist government relocations given the recent movement of the town's wood industry against all odds. Others could not give open answers to this question as they were acting as caretakers of family property. However, the tenants are obviously more open to the idea of relocation than the Landlords given their relative interest in the properties they occupy. Yet, in any redevelopment agenda both tenants and landlords need to be treated as primary stakeholders in arriving at decisions. All affected would have to be assured of the preservation (if not the improvement) of their interests in properties demolished to make way for the redevelopment agenda.

\section{Conclusions and Recommendations}

While the slum problem is a real one confronting 
economists, environmentalists, politicians and development practitioners alike, there has been a lack of clear cut policy to dealing with situation apart from the simplistic approach which has been found as retrogressive. It is against this background that this paper investigated the feasibility of slum redevelopment through the regenerative approach. Based on the UN Habitat definition of a slum with emphasis on structural quality of housing, levels of overcrowding, access to safe water, sanitation, tenure security, income levels and social deprivation of inhabitants; the paper posited that slum-friendly approaches based on redevelopment are preferred to slum-free approaches based on slum clearance. From results and discussions, it is apparent that the best chance the nation has in dealing with slums is by the adoption of the regenerative approach to slum redevelopment. Despite its complexity it is obviously a more cost effective way of dealing with slums as against the simplistic model of slum clearance and rebuilding based on traditional ideals spelt out by western planning theory.

Dealing with slums in a regenerative manner could be justified by the fact that their existence is a drawback on the development of the nation as a whole. Slum redevelopment could be considered as highly feasible if given priority attention by governments and part of the considerable resources (internally generated and from international aid) available and assessed by the nation are applied to deal with slum redevelopment in a programmed manner. Knee-jerk reactions of slum clearance in response to national disasters cannot effectively deal with the problem of slums. It is however worth noting that slum eradication by a single government is impossible given the scarcity of resources available to the nation at any given point in time and the necessary procedures that need to be followed through. Thus crucial to the issue of slum redevelopment is the fact of 'political will'. This can however be gotten through more attention drawn to the hazards of 'the slum phenomena' by the media, NGOs and civil society groups at public forums.

In dealing with the slum menace, the root causes - poverty and weak land governance and planning systems must be simultaneously dealt with. This should be done through effective measures of wealth generation by the citizenry through innovative ideas as opposed to simplistic poverty alleviation measures such as the Livelihood Empowerment Against Poverty (LEAP) where periodic small cash sums are doled out to deprived sections of society that cannot create further wealth and simply have to be spent on survival needs such as food. Such innovative ideas of wealth generation include entrepreneurship training skills for self-employment, especially for the youth of the country. On the land side of the issue, improved legal and institutional reforms in the land and planning sectors of the country as envisaged under the current reforms of the on-going Ghana Land Administration Project (GLAP I \&II) have a lot to answer if nothing meaningful is achieved at the end of the Project.

\section{REFERENCES}

[1] Hardoy, J. E. and D. Satterthwaite, Squatter Citizen, London, Earthscan Publications, 1989.

[2] Nevitt, A. A. "Slums and Poverty', The Economic Problems of Housing, London, Macmillan, 1967.

[3] UN Habitat, Global Report on Human Settlements: Enhancing urban Safety and Security, UNHSP, Earthscan, 2007.

[4] Anno, L. An Appraisal of Urban Renewal Schemes, Case study of Koforidua Redevelopment Scheme, An Unpublished thesis submitted to the department of Land Economy, K.N.U.S.T., 1982

[5] Tibaijuka, A., Executive Director of UNCHS (Habitat), Available from www.gdrc.org/uem/index.html, 15 March, 2009.

[6] UN Habitat, Global Report on Human Settlements: Cities and Climate Change, UNHSP, Earthscan, 2011.

[7] Songsore, J. The Urban Transition in Ghana: Urbanisation, National Development and Poverty Reduction, Study prepared for the IIED as part of its Eight Country Case Studies on Urbanisation, IIED, London, Undated.

[8] Srinivas, H. 'Urban Squatters and Slums Defining Squatter Settlements' (Available from www/gdrc.org/squatters/squatt ers.html), 2005

[9] Bugri, J. T. Improving land sector governance in Ghana: an application of the Land Governance Assessment Framework (LGAF), World Bank, Washington, DC. 2012.

[10] Ezeigbo, O., and M. Odoguje, Africa: Slums, Fresh Challenges Before Sub- Saharan Africa, (Available from http;//www.allafrica.com/stories.html) 2008.

[11] IEA, Housing Policy in Ghana: Providing Incentives to Investors and Consumers, Legislative Alert, Vol. 1 No. 2, Institute of Economic Affairs, Accra, 1993.

[12] Payne, G.K. Urban Housing in The Third Word, Leonard Hill, Great Britain, pp. 65-81, 1977.

[13] Jones, G. A. The Difference Between Truth and Adequacy: (Re)-joining Baken, van der Linden and Malpezzi, Third World Planning Review 18 (2) pp. 243- 256, 1996.

[14] Abrams, C. Housing in the Modern World: Man's Struggle for Shelter in an Urbanising World, London, Faber and Faber Ltd, 1965.

[15] Yin, R. K. Case study research: Design and methods, Newbury Park, CA: Sage, 1984

[16] Hosenfeld, C. Case studies of ninth grade readers. In J.C. Alderson and A.H. Urquhart (Eds.), Reading in a Foreign Language, London, Longman, 1984.

[17] Zaidah, Z. An Investigation into the effects of Discipline-Specific Knowledge, Proficiency and Genre on Reading Comprehension and Strategies of Malaysia ESP Students. Unpublished Ph.D. Thesis. University of Reading, 2003.

[18] Hamel, J., Dufour, S. and Fortin, D. Case Study Methods. Newbury Park, CA: Sage Publications, 1993.

[19] Baxter, J., Eyles, J. Evaluating qualitative research in social 
geography: establishing 'rigour' in interview analysis. Transactions of Institute of British Geographers, 22 (4), pp505-525, 1997.

[20] Appiah , E., Photos: Sodom and Gomorrah demolished, Ghana|Myjoyonline|Edwin Appiah|edwin.appiah@myjoyonline.com, http://www.myjoyonline.com/news/2015/June-20th/photos-s odom-and-gomorrah-demolished.php,20-06-2015Time: 07:06:00:pm

[21] Frimpong, D. E., KMA demolishes 'Abinkyi' slum in Kumasi, http://enochdarfahfrimpong.blogspot.com/2010/05/ kma-demolishes-abinkyi-slum-in-kumasi.html, Thursday, May 27, 2010

[22] Ghana/starrfmonline.com/103.5FM, CHRAJ condemns
Sodom and Gomorrah demolition, http://www.starrfmonline. com/1.4719880, Jun 24, 2015 at 6:52pm

[23] CRESWELL, J. W. Research Design: Qualitative and Quantitative Approaches (Sage Publications, California). 1994.

[24] Easterby-Smith, M., Thorpe, R. And Lowe, A. Management Research (Sage, London, UK). 1991

[25] Duah, E. And Bugri, J.T., Feasibilty of Slum Redevement in Ghana -A case Study of Anloga-Sobolo, http://ir.knust.edu.gh/handle/123456789/6197, May 2014

[26] Tweneboa, A. Providing Affordable Housing In Ghana, 3rd Annual Affordable Housing Projects Hilton Kuala Lumpur Hotel , Malaysia, 2012 